\title{
Accessing the public workforce: Organisational recruitment practices and the inclusion or exclusion of individuals of immigrant origin
}

\section{Christine Lang(D}

Correspondence: lang@mmg.mpg. de

Max Planck Institute for the Study of Religious and Ethnic Diversity, Göttingen, Germany

\begin{abstract}
Organisations are important gatekeepers in the labour market inclusion of immigrants and their children. Research has regularly documented ethnic discrimination in hiring decisions. Aiming to further our understanding of the role of organisations in influencing the professional trajectories of individuals of immigrant origin, this paper investigates the recruitment practices of public administrations. Drawing on approaches from organisational sociology and a qualitative case study of public administrations in the German state of Berlin, the article identifies three crucial elements of organisational decision-making affecting the recruitment of staff of immigrant origin: decisions regarding advertisement strategies, formal criteria, and individual candidates. Further, the article shows the underlying decision-making rationalities and the role of organisational contexts and ethnic stereotypes for recruitment-related decisions.
\end{abstract}

Keywords: Organisations, Public administration, Staff of immigrant origin, Recruitment, Employment, Ethnic discrimination, Germany, Labour market incorporation

\section{Introduction}

The incorporation of immigrants and their children in the labour market is a key aspect of societal inclusion and has been a long-standing research topic in migration studies (e.g. van Tubergen et al. 2004; Heath and Cheung 2007; Kogan 2007; Pichler 2011). We also witness increasing scholarly interest in the professional trajectories of individuals of immigrant origin (e.g. Crul et al. 2012; Nohl et al. 2014; Konyali 2017; Keskiner and Crul 2017; Lang et al. 2018). This literature mainly focuses on institutional and individual-level factors shaping labour market opportunities and professional careers. It has less investigated the role of work organisations. Notably studies on hiring discrimination show the relevance of organisational decisions for the access to employment. Experimental studies demonstrate that applicants with an immigrant or ethnic minority background have lesser chances to be invited to interviews (for an

(c) The Author(s). 2021 Open Access This article is licensed under a Creative Commons Attribution 4.0 International License, which permits use, sharing, adaptation, distribution and reproduction in any medium or format, as long as you give appropriate credit to the original author(s) and the source, provide a link to the Creative Commons licence, and indicate if changes were made. The images or other third party material in this article are included in the article's Creative Commons licence, unless indicated otherwise in a credit line to the material. If material is not included in the article's Creative Commons licence and your intended use is not permitted by statutory regulation or exceeds the permitted use, you will need to obtain permission directly from the copyright holder. To view a copy of this licence, visit http://creativecommons.org/licenses/by/4.0/. 
overview see Zschirnt and Ruedin 2016), and research on employer decision-making confirms discrimination in selection decisions (Jenkins 1986; Kirschenman and Neckerman 1991; Moss and Tilly 2001; Imdorf 2008; Scherr et al. 2015). Valuable insights into the organisational conditions for immigrants' and ethnic minorities' professional inclusion are also provided by studies on diversity policies in organisations (e.g. Kalev et al. 2006; Groeneveld and Verbeek 2012; Dobbin et al. 2015) and the accommodation of and discourses about diversity at the workplace (e.g. Zanoni and Janssens 2015; Dobusch 2017; Adam and Rea 2018); yet this research focuses less on concrete recruitment practices.

This article aims to contribute to the understanding of the role of organisations in influencing professional trajectories of individuals of immigrant origin ${ }^{1}$ by examining how different organisational practices shape the access to employment and how they are affected by organisational contexts. I will do this by combining literature on hiring discrimination with approaches from organisational sociology and looking at the access to public administrations. Access to the public workforce is not only an important aspect of labour market inclusion, but also a matter of representation in core institutions of the nation-state and therefore concerns societal participation and belonging more profoundly.

Empirically, the article investigates the recruitment of junior staff members of immigrant origin in public administrations in Germany, specifically in the city-state of Berlin. In the German public workforce, the underrepresentation of immigrants and their children is particularly pronounced in international comparison (OECD 2018, p. 209). The German sample census shows a share of staff with a "migration background" in public administration of 6.7\% in 2013 (Ette et al. 2016, p. 32), compared with a share of $19.7 \%$ in the overall population the same year (Statistisches Bundesamt 2014). ${ }^{3}$ At the same time, public policies have declared the objective to increase the share of administrative staff members with a migration background since the mid-2000s, which poses new demands on administrative recruitment. The state of Berlin provides an interesting terrain for this study since it allows comparing recruitment practices in different local (i.e. district) administrations situated in the same institutional setting, thus particularly uncovering the role of the organisational level. The numbers of new hires with a migration background considerably vary between Berlin's local administrations, raising the question of factors explaining organisational differences.

Based on a comparative case study in three district administrations and extensive qualitative data (semi-structured interviews, participant observation, political and administrative documents), the article identifies three crucial elements of decision-making in the recruitment process affecting the inclusion of individuals of immigrant origin: decisions regarding advertisement strategies, regarding formal selection criteria and regarding individual candidates. Further, the analysis shows that recruitment-related decisions are primarily based on pragmatic considerations of internal and external demands and shaped by organisational structures and ethnic stereotypes.

\footnotetext{
${ }^{1}$ In the case of Germany investigated here, the group in question is defined in immigration-related terms. Many aspects studied might also apply to "ethnic minorities" in other contexts.

${ }^{2}$ The official statistical category "migration background” (Migrationshintergrund) is defined as: „A person has a migration background if he or she or at least one parent does not have German nationality by birth“(Statistisches Bundesamt 2018, p. 4).

${ }^{3}$ More detailed data is not available since employee statistics do not record a "migration background".
} 
In the following, I will first discuss the literature on organisational hiring discrimination and connect it with insights from organisational sociology on organisational decision-making. After introducing the empirical case, data and methods in the third section, the fourth section presents the findings of the analysis of recruitment practices in public administrations in Berlin. The final section summarizes and discusses the findings.

\section{Organisations and workforce in/exclusion of immigrants and ethnic minorities}

Analysing organisational recruitment processes is crucial to understand factors influencing inclusion in or exclusion from the workforce (Windolf 1986). Research on hiring discrimination indicates different organisational mechanisms leading to the exclusion of immigrants and ethnic minorities. I combine this literature with theoretical approaches from organisational sociology to understand the underlying decision-making rationalities and premises.

The recruitment channels are a first mechanism identified as affecting the inclusion of individuals of immigrant or ethnic minority background. Empirical studies particularly document that recruitment based on networks and staff recommendations creates disadvantages for these individuals if they are not present among the existing staff or occupy only low-status positions (Jenkins 1986, pp. 120-121; Bommes 1996; Kasinitz and Rosenberg 1996; Waldinger and Lichter 2003; Meziani-Remichi and Maussen 2017). Less attention has been paid to the impact of other recruitment channels (but see Rivera 2012). Network-based hiring helps to solve a core problem of organisational decision-making. Both behavioural theory and systems theory in organisational sociology emphasize that organisational decisions are taken under conditions of uncertainty and bounded rationality (March 1990, pp. 266-293; March and Simon 1993, pp. 157192; Luhmann 2000, pp. 183-221). Disposing of only limited time, resources, and information about the candidates, employers have to reduce uncertainty regarding their suitability with manageable effort (Imdorf 2008, pp. 119-120). Making use of networks serves this purpose by providing a relatively reliable source of information and an efficient way to find suitable candidates (Jenkins 1986, pp. 138-146).

Second, the inclusion of immigrant-origin or ethnic minority candidates may be affected by categorical distinctions that employers draw upon in their selection. The concept of statistical discrimination describes that employers turn to knowledge about the average productivity of different categories of people in their evaluation of candidates because they lack sufficient information about the individual applicants and obtaining it would be too costly (Phelps 1972). Socio-psychological research shows the stereotypical nature of these assessments (Pager and Karafin 2009). From an organisational perspective, drawing on stereotypes again helps to reduce uncertainty and limit the effort invested in hiring decisions. Several empirical studies show that employers exclude candidates from certain ethnic or national backgrounds in the selection because they presume lacking skills and a lacking fit to the company culture or customers' expectations (e.g. Kirschenman and Neckerman 1991; Moss and Tilly 2001; Imdorf 2008; Scherr et al. 2015). The literature suggests that the likelihood for this form of discrimination is lower in public organisations (Midtbøen 2014; Zschirnt and Ruedin 2016, p. 1126) due to their more formalized and standardized procedures 
(Midtbøen 2015, p. 207). However, in-depth research on public organisations is scarce (but see Meziani-Remichi and Maussen 2017). Moreover, ethnic distinctions may matter in more subtle and unconscious forms via "in-group preference" (Stainback et al. 2010, pp. 228-229) or representations of suitable employees that are shaped by the established "white" norm (Acker 2006). This may also serve to reduce uncertainty for the organisation since 'normal candidates' promise less risk and a higher likelihood to fit into the workforce.

Third, the concept of 'institutional(ized) discrimination' points out that organisational practices may indirectly discriminate against individuals of immigrant or ethnic minority background by applying presumably neutral and fair procedures, which, nevertheless, produce inequalities. This can be due to prior discriminatory practices or discriminatory practices in other sectors such as the education system (Feagin 1977). A study on institutional discrimination in schools shows that organisational selection practices can discriminate if they are based on expectations from 'normal' students, which immigrant children are less likely to meet (Gomolla and Radtke 2009, p. 274). Organisations may then draw on ethnic stereotypes to legitimize a posteriori the inequalities indirectly produced by their selection (Gomolla and Radtke 2009, pp. 275-276). By justifying unequal outcomes with common negative stereotypes, e.g. about lacking skills, an organisation can externalise the reasons for the inequalities and gain acceptance for its decisions in the environment. The use of categorical distinctions and stereotypical knowledge may thus help legitimizing organisational practices and inequalities. This reflects insights from neo-institutionalist approaches in organisational sociology. They emphasize that organisational practices and structures have to signal compliance with societal rules, norms and beliefs to secure the organisation's legitimacy and survival (e.g. Meyer and Rowan 1977; Scott 2008, pp. 59-62). For administrative recruitment practices, this includes compliance with principles of equal treatment and meritocracy, but also with political objectives to increase diversity in the workforce.

The literature thus emphasizes different organisational mechanisms barring the access of immigrants and ethnic minorities to employment as well as rationalities informing organisational practices, namely responding to the requirements to reduce uncertainty and to secure legitimacy. Yet, it remains an open question whether and how they operate in public administrations, an understudied type of organisations. Further, our knowledge about factors that may explain differences between organisations is patchy. Studies suggest a role of professional sectors (Jenkins 1986; Midtbøen 2014), "labour market power" and "organisational intelligence" (Windolf 1986) or regional contexts, organisational size and orientation (Scherr et al. 2015), but in-depth comparative studies of organisations of the same type are lacking. To study organisational differences, the systems theory approach in organisational sociology provides a useful framework (Luhmann 2000; Kühl 2013). Taking a radically constructivist perspective, this approach emphasizes that organisational decisions are contingent on the organisation-specific structures and observation schemes. Organisational structures, or "decision premises", are conceived in three types (which can be formal and informal). They include 'programmes', which define when, how and for which purposes decisions are made (in forms of rules, plans, strategies); 'communication channels' that define which 
positions take what kind of decisions and give or receive orders; and the 'personnel', i.e. staff members with their characteristics. ${ }^{4}$ Decisions may further be informed by the culture and identities of the organisation. Drawing on this approach, we can thus assume that such organisation-specific features influence recruitment-related decisions.

\section{Empirical case, data and methods}

The study draws on a comparative case study of local administrations in the German state of Berlin and extensive qualitative data gathered from 2012 to 2015. As a citystate, Berlin provided a fruitful terrain for the research. It is constituted of 12 districts, which represent the local level and enjoy relative autonomy in matters of staff recruitment. This allowed comparing recruitment practices in different district administrations situated in the same institutional context and specifically shedding light on the organisational level. Since 2005, the city-state's integration policies include the objective "to increase the share of employees with a migration background" in public administration under the headings of "labour market integration" and "intercultural opening" of public institutions (Der Beauftragte des Senats von Berlin 2005; Abgeordnetenhaus von Berlin 2010). Concrete measures mainly focus on the vocational training (Ausbildung). In Germany, this is a highly institutionalized and recognized pathway into a large range of qualified occupations. The three-year training, which requires a secondary school degree, combines a traineeship in the employing organisation with theory at vocational schools. In public administration it is the entry requirement for the middle grade of the civil service (e.g. administrative clerk positions). Internal careers can lead up to the middle management. After successful completion of the training, trainees are usually offered continued employment. Vocational training was the main form of regular recruitment in Berlin during a period of staff cuts from the late 1990s to the early 2010s.

The empirical research focused on the access to vocational training for administrative occupations, as the main target of the policies and to guarantee comparability across administrations. In 2006, the city-state launched a campaign called "Berlin braucht Dich!" ("Berlin needs you!") aiming at promoting vocational training in the civil service among young people of immigrant origin. It has become a comprehensive programme that supports internships, provides promotion material and facilitates contacts between employers and schools. District administrations are expected to participate, but the state government cannot enforce this. Recruitment numbers of trainees of immigrant origin differ between Berlin's administrations. Since official employee statistics in German public administration do not record the category "migration background", statistical data is very limited. However, the "migration background" of new trainees has been registered in Berlin since 2006. When fieldwork was conducted, a few districts had regularly shown shares of new trainees with a migration background between 25 and $50 \%$, whereas in others the numbers had varied largely between the years, and some districts had rarely reported shares of more than 10\% (BQN Berlin 2014).

The qualitative data collected for this research includes different types. These are, first, 60 semi-structured interviews plus several informal talks with respondents that

${ }^{4}$ Persons are conceptualized as organisational structures based on the systems theory premise that communication and not action is the basic unit of organisations. They are a structuring element of communication as authors, addressees and topics of communication. 
were selected following the objective to include the relevant actors involved in recruitment processes and the politics to increase the share of staff members with a migration background on the state and district levels. Interview participants ${ }^{5}$ encompass ten vocational training officers, eight heads of administrative departments (HR, citizen services, youth welfare service), six integration commissioners, three members of district parliaments, three representatives of NGOs offering projects to support young people of immigrant origins' access to the civil service and 28 trainees and employees of immigrant origin to include the perspective of (former) candidates. ${ }^{6}$ Second, I conducted participant observation in the trainee recruitment process (e.g. in the selection of applications, in interviews, at job fairs). In one district administration I could shadow the vocational training unit for two weeks, in two administrations for several single days during the recruitment period. This also allowed observing everyday work routines and holding informal conversations. Third, I analysed a large body of political and administrative documents to reconstruct the problematisation of the access of individuals of immigrant origin to public administration. Data collection was continued until saturation was reached, i.e. until new material did not contribute new information regarding the research questions (for more details on the data collection see Lang 2019).

The empirical data was analysed drawing on grounded theory (Strauss and Corbin 1990), supported with the software MAXQDA. An inductive content analysis was combined with fine-grained, hermeneutic analyses of key passages to reconstruct the logics of action and interpretation schemas underlying recruitment practices. Codes included, among others, the different elements of the recruitment process, the recruitmentrelated considerations of the actors in charge, the modes of differentiating potential candidates of immigrant origin, the elements of the organisational context relevant for recruitment practices, references to the local context (e.g. the population), features of the institutional environment, and the trajectories, experiences and perceptions of trainees/employees of immigrant origin (for more details see Lang 2019).

The in-depth comparative case study focused on three district administrations. Case selection was based on documents, first interviews and data on trainees with a migration background. The criterion was to include contrasting cases regarding the recruitment of these trainees and responses to the city-state's diversity policies. Based on qualitative case study methodology (George and Bennett 2005), the objective was to reconstruct through within-case analyses and cross-case comparison the mechanisms and the interaction of factors contributing to the observed differences.

In administration A, recruitment practices had continued unchanged and shares of newly-hired trainees with a migration background remained usually below $10 \%$. The district in the Western part of Berlin has one of the highest proportion of inhabitants with a migration background (ca. 36\% in 2014 when fieldwork was conducted) but is commonly more associated with its bourgeois neighbourhoods. In administration B, a district situated in the Eastern part of Berlin with a significantly lower share of inhabitants with a migration background (ca. 17\% in 2014), temporary efforts to hire more trainees with a migration background led to proportions of more than $20 \%$ among the

\footnotetext{
${ }^{5}$ With some core actors, I conducted two interviews; three interviews included two participants.

${ }^{6}$ All staff members of immigrant origin interviewed grew up and completed school in Germany (some had migrated as children with their parents). Their age ranged from 20 to 50; the large majority was in their 20s. Family backgrounds included Turkey, Lebanon, Ukraine, Poland, Kazachstan, Vietnam, Iran.
} 
newly-recruited trainees, but these efforts were abandoned after some years, and numbers had dropped again to below 10\%. In administration C, a district in the Western part of Berlin, which has a high proportion of inhabitants with a migration background (ca. 42\% in 2014) and often features in public discourse around immigration-related problems, several measures had been introduced to increase the share of trainees with a migration background and numbers had regularly figured around $25-35 \%$. Beyond these differences, the administrations shared basic characteristics such as size (approx. 2000 staff members), tasks (e.g. offices for citizen services, social welfare, youth welfare, urban development, public order), hierarchical structure, "labour market power" (Windolf 1986), formal requirements on trainees as well as political affiliation of the mayors (in all cases members of one of the governing parties in the city-state, Social democrats or socialist Left).

\section{Administrative recruitment practices and the in/exclusion of individuals of immigrant origin}

In Berlin's district administrations, trainee recruitment was a highly standardized, yearly procedure. The administrations received several hundred applications for 10-30 trainee positions for administrative occupations each year. ${ }^{7}$ The recruitment was conducted by the vocational training unit, a subunit of the personnel department, which was typically in the areas of responsibility of the district's mayor. Since candidates usually applied for several trainee positions at the same time, also in several administrations, the selection had to be processed as efficiently as possible to avoid that the good candidates already accepted job offers elsewhere.

Recruitment and selection procedures differed between administrations. The comparative analysis shows particularly three elements of decision-making that affected the inclusion of individuals of immigrant origin: decisions regarding advertisement strategies, regarding formal selection criteria and regarding individual candidates. Further, it reveals the underlying decision-making rationalities and the role of ethnic stereotypes and it indicates elements of the organisational contexts contributing to differences between administrations.

\section{Advertisement strategies}

The comparative case study shows, first, the importance of advertisement strategies for the inclusion/exclusion of immigrants and their children. The administrations studied publicly announced their open positions, and candidates were selected in a formal procedure; hiring did not directly draw on networks, which may be a source of exclusion (e.g. Jenkins 1986; Bommes 1996; Kasinitz and Rosenberg 1996; Waldinger and Lichter 2003). However, networks mattered indirectly. The interviews with trainees and employees of immigrant background who had successfully entered the administrative workforce show informational and symbolic barriers to applications. Only three out of 28 respondents had initially considered applying at public administrations; the others only coincidentally heard from this occupational opportunity e.g. via teachers, occupational counsellors or, in a few cases, friends or relatives who had recently completed

${ }^{7}$ Hiring numbers differed between administrations and increased at the end of the 2010s due to growing recruitment needs. Administrative occupations accounted for the majority of trainees, but the administrations also hired for other occupations (e.g. gardeners and librarians). 
vocational training in public administration. Hardly anyone had come across advertisement. Their narratives illustrate a lack of knowledge about entry and career opportunities in public administration partly due to lacking networks to people working there. Their parents' generation was usually not employed in German public administration since they lacked the required special training and citizenship to become civil servants. ${ }^{8}$ Further, respondents had often perceived the civil service as difficult to enter. One young woman with Turkish background explained for instance: "Maybe it was something out of reach for me. [...] I always thought you had to study to get into the civil service." (Interview M2, \$94). ${ }^{9}$ To lower these barriers, active advertisement is of key importance. Doing without it may lead to indirect network recruitment since it increases the importance of contacts to people working in the administration to learn about employment opportunities (Marsden and Gorman 2001, p. 473).

The three administrations examined in the in-depth case studies took different decisions regarding advertisement. The analysis presented below shows that they were primarily based on pragmatic considerations of the officers in charge as to whether additional effort is needed to attract enough qualified candidates. It further indicates how these considerations were shaped by the organisational contexts and substantiated by ethnic stereotypes.

In administration $\mathrm{A}$, where numbers of newly-hired trainees of immigrant origin were low, the vocational training unit did not advertise the open positions beyond placing the announcement on the website. The officers blamed their limited resources, but they did also not perceive the need for advertisement activities since they would have "no problems" allocating their trainee positions to good applicants as the head of the unit emphasized (Interview A3.1, \$62). A significant decrease in application numbers since some years, which concerned all administrations in Berlin - reflecting demographic changes and declining numbers of young people choosing vocational training - was not yet perceived as a problem requiring action. Further, the administration only participated on paper in the city-state's campaign "Berlin needs you!", which aimed at attracting young people with a migration background to the civil service. The officers understood the campaign as a scheme to improve the labour market inclusion of young people with integration problems, i.e. not their preferred target group. The head of the unit argued:

"In my view, there is for sure a need to support the persons concerned, but not in the question of hiring them for civil service positions, but in the question, how can they be motivated to be able to perform correspondingly, [...] also the language background [...] that language skills are sufficiently developed, simply because this is necessary for the job. [...] We would actually have to start two levels earlier, even in early childhood, right? [...] and that is not the task of the employers, that is a political decision, how do I deal with this in the school system. But we can only act and

${ }^{8}$ Only German and EU citizens can become civil servants. Since the restrictive German citizenship law until 2000 only granted citizenship after a long and demanding naturalisation procedure, many children of nonEU-immigrants born in Germany were precluded from access to the civil service.

${ }^{9}$ Translation of all interview quotes by the author. References indicate the interview code and the paragraph number in the interview transcript. 
bear the fruits that then result from supporting this group of people." (Interview A3.1, \$125).

Perceptions of young people of immigrant origin as lacking essential skills both motivated and justified the decision not to participate. They helped to reduce uncertainty about advertisement needs and legitimize the decision not to undertake additional promotion activities vis-à-vis political and public expectations that employment of this category should be promoted.

The officers' perceptions and practices were embedded in an organisational context, in which neither a formal policy on 'intercultural opening' nor a future-oriented HR strategy existed. The district's mayor, in charge of both domains, hardly showed interest in these issues, and due to the district's rather bourgeois identity, despite its large immigrant population, public expectations on the implementation of diversity policies were lower than for the prominent immigrant districts of Berlin (Lang 2017, 2020). Hence, no expectations were communicated that would have required the officers to enhance their promotion activities.

In administration $\mathrm{B}$, in contrast, the vocational training unit had, for some years, actively participated in the "Berlin needs you!" campaign and promoted their vocational training in local immigrant associations. This responded to the declared objective of the former district's mayor to recruit more employees with a migration background, as part of a formal 'intercultural opening' policy. It included a tightly-controlled target for the share of trainees with a migration background. However, when the mayor retired, the successor stopped pursuing the policy and the vocational training officers abandoned their advertisement activities since the need to report on efforts to meet the target ceased to exist. As different from administration A, however, they strove to develop new promotion strategies in view of the decreasing application numbers. The head of the unit explained: "Publicity will increase in our sector, because in the future we will look for applicants, not the other way around. We will have to do a lot more" (Interview B1.1, \$28). But the officers' suggestions did not receive support from the superiors; the head of the HR unit, deeming the number of applications still enough, cut down resources for advertisement. Further, the target groups of the promotion activities no longer specifically included young people of immigrant background. The formerly enforced target had caused conflicts. The officers had hired candidates just because of their 'migration background', in order to meet the target. Since some of them had not shown good performance, the officers now associated 'migration background' with lacking suitability. They generalized the negative experiences with few trainees into the now 'justified' expectation that these trainees would risk causing problems, ignoring the much larger number of successful trainees. As in administration A, stereotypes about young people of immigrant origin as not meeting expectations on future staff members substantiated the decision to stop pursuing specific promotion activities. One officer described for instance "Turkish girls" as risky candidates: "They do the training, then they are sent to Turkey to marry some third-degree cousin and stay there. We won't get anything from them here anymore " (conversation protocol B3, \$115). For the officers, the political objective clashed with their recruitment interests. This also discredited the city-state's campaign "Berlin needs you!" and they had ceased participating. 
In administration $\mathrm{C}$, decisions for active advertisement seemed to contribute to lowering barriers to applications of children of immigrants. Initiated by the district's mayor, who pursued an integration policy agenda, the vocational training unit took a leading role in the steering committee of "Berlin needs you!" and used its instruments to promote their vocational training in schools and via internships for young people with a migration background. While these activities had first been politically motivated and responded to public expectations which particularly focused on this prominent immigrant district (Lang 2020), they also corresponded to the vocational training officers' recruitment rationalities. Like their counterparts in administration $\mathrm{B}$, they perceived a growing competition for suitable candidates. In contrast, however, they embraced the instruments provided by the "Berlin needs you!" campaign. They could hardly ignore young people of immigrant descent in their endeavor to increase the pool of candidates given that they represented an important share of school graduates in this district. But beyond the campaign's focus on this category, the officers used its tools for their general advertisement strategies. The head of the training unit explained: "Of course, with this I have promoted the town hall [...] as an employer brand. Because many people on the streets here don't even know about the vocational training here [...] and it's of course an advertising platform for us, to present ourselves as employers: 'Look, we have a great training programme, we have the opportunities after the training, look how great we are” (Interview C2, \$66). Moreover, the unit developed further promotion strategies to present the administration as an attractive employer for a young, diverse public. This included a YouTube clip adapted to the lifestyle preferences of the urban youth, in which a young staff member with a Turkish name presented the vocational training. Different from the other two cases, these advertisement efforts met the support of the district's mayor, who provided the necessary resources, aware of the upcoming recruitment demands and interested in promoting the vocational training.

\section{Formal selection criteria}

While the literature suggests that formalisation of selection procedures reduces discrimination against candidates of immigrant or minority background (e.g. Jenkins 1986; Midtbøen 2015; Zschirnt and Ruedin 2016), the administrative recruitment practices studied indicate that formalised and standardised procedures may also create unequal access opportunities. Formal selection criteria did not include specific language and intercultural skills, nor did they consider a 'migration background' in any of the cases investigated. Criteria had not changed in view of the political objective to recruit more staff with a migration background. Selection was formally based on the principle of meritocracy. However, meritocratic selection could legitimately apply different criteria. To a certain extent, meritocracy proves to be contingent: the selection decisions are based on decisions for criteria that could have been different.

For the selection of candidates that were invited to recruitment tests and interviews, Berlin's public administrations used basically two types of formal procedures and criteria. Some administrations drew on educational achievements. They included educational degrees (at least secondary school level), school grades (at least satisfying in the main subjects) and unauthorized absences marked on the school certificates (none). Based on this, candidates were invited to a test, which included classic elements of German spelling, grammar, mathematics and general education. Other administrations had 
recently introduced a 'suitability assessment' with criteria independent of educational achievements, which was supported by the state government and conducted by an external HR service provider. Here, applicants first had to pass an online pre-test, successful applicants were invited to a written test, which was adapted to the job profile and included e.g. elements on logical thinking, work efficiency and knowledge relevant to administration. Both types of procedures and criteria could draw on recognized authorities - the school institution or a designated HR expert organisation - thus guaranteeing the legitimacy of the selection.

The comparison of administrations $\mathrm{A}$ and $\mathrm{C}$ illustrates how decisions regarding selection criteria may impact on the access of individuals of immigrant origin and elucidates factors shaping decision-making. In administration A, the vocational training unit used the first type of criteria, and additionally considered the educational trajectory. Candidates who took the classic route into vocational training, applying directly after graduating from secondary school, were prioritised over those with less linear educational pathways (e.g. who dropped out of university studies or had previous vocational training). The vocational training unit in administration $\mathrm{C}$ applied the new 'suitability assessment'. While the proportion of trainees with a migration background in administration A rarely surpassed $10 \%$, in administration C it regularly exceeded $30 \%$. These different outcomes seemed to be related to the selection criteria. It was striking that hardly anyone of the candidates who were invited to interviews in administration A had a migration background. On the other hand, many of the trainees with a migration background who were hired in administration $\mathrm{C}$ during the time of my fieldwork would have been sorted out in administration A due to their educational degrees, grades or because they had started and discontinued university studies.

Research on the educational pathways of immigrant children suggests that these observations are not coincidental. Selection criteria in administration A reproduced performance assessments by schools and thus inequalities affecting children from immigrant and working-class families that schools produce or enhance (e.g. Gomolla and Radtke 2009; Becker and Reimer 2010; Diehl et al. 2016). Further, they favoured applicants for whom vocational training in public administration was an attractive option after secondary school despite good grades and thus good chances to attain Abitur, the final school qualification that grants access to higher education. In view of the regularly shown high educational aspirations in immigrant families (Salikutluk 2016; Hadjar and Scharf 2019), as well as the lacking knowledge about career options in public administration described above, it is not surprising that immigrant children were hardly represented among the highly-ranked candidates in administration A. This case thus indicates a form of "institutionalized discrimination" (Feagin 1977; Gomolla and Radtke 2009): the presumably neutral criteria could disadvantage children of immigrants due to their disadvantages in the education system and lacking knowledge about the occupation.

Decisions regarding selection criteria in these two administrations drew again on pragmatic considerations regarding the effort required, partly justified by negative ethnic stereotypes. Again, the organisational contexts also mattered. In administration A, the officers continued the established procedure despite the state's attempt to make all administrations introduce the centrally-organised 'suitability assessment'. Due to the district administrations' autonomy in recruitment issues, this central assessment could 
not be forced. Emphasizing that they "fared very well since years" with their procedure (head of the unit, Interview A3.1, $\$ 12$ ), the officers did not see a practical need to invest effort in changing routines. Further, as described above, the district's mayor, in charge of the HR department, did not communicate interest in the trainee recruitment that would have required revising the routines. The procedure was not questioned for its possible discriminatory effects.

The officers justified the low numbers of recruited trainees with a migration background with deficiencies of young people of immigrant origin, particularly distinguishing those with Turkish and Arab background. The head of the unit argued for instance: "Turkish and Arab young men, from my experience, have much more difficulties to make it here, because, I think, they experience another influence. Maybe they don't want to work in the civil service [...]. Often, they also don't pass the tests, if they are invited at all” (Interview A3.1, \$110). Similarly as it has been described for institutional discrimination in schools (Gomolla and Radtke 2009), this allowed legitimizing the selection outcomes and masking how the organisational selection criteria may contribute to the inequalities in the access to the vocational training. Emphasizing lacking qualifications of young people of immigrant origin externalized the reasons for the inequalities and substantiated that the own practices complied with the norm of meritocracy. This supported the legitimacy of the organisation, which is crucial for its survival (Meyer and Rowan 1977). Further, it helped reducing uncertainty regarding the selection procedure in a context where new environmental expectations - to recruit more trainees with a migration background - challenged well-established routines and enhanced uncertainty.

In administration $\mathrm{C}$, the decision to introduce the new 'suitability assessment' was also based on pragmatic considerations regarding the effort required, though with different results. The head of the vocational training unit explained: "It just had something to do with work. [...] The [earlier] test had to be evaluated by myself and that was simply inefficient in terms of effort. I had to invest so much time into it that I tried to see how we could make the whole process more efficient. [...] And then, after a calculation of the profitability [...] we decided to do it differently" (Interview C2, \$8). The fairness of the procedures or possible discriminatory effects were also not considered. In contrast to administration A, the organisational context favoured such changes. As mentioned above, the district's mayor showed high interest in the vocational training. He supported the officers' suggestion to introduce a new procedure and an additional position for an officer in charge of it was created. The comparison thus shows how the interest of the personnel in the relevant decision-making position may support innovation, while its lack may contribute to the inertia of established procedures.

\section{Selection of individual candidates}

Decisions over candidates that were offered a position were a third important element of decision-making affecting the inclusion of candidates of immigrant origin. This moment is often identified as the main gate for discrimination based on categorical distinctions and stereotypes (e.g. Kirschenman and Neckerman 1991; Moss and Tilly 2001; Imdorf 2008; Scherr et al. 2015). In the administrations investigated, these decisions were established through a formalised and standardised procedure, which left 
little scope for direct discrimination. The interviews followed standardised questionnaires and the candidates were evaluated with standardised evaluation sheets, which included numerical scales for various criteria (e.g. "motivation", "communication skills", "verbal skills"), translating personal impressions into numbers. These were calculated with the points achieved in the test, leading to a final score that condensed the suitability of an applicant and allowed the establishment of a supposedly objective ranking.

The objective, 'difference-blind' selection of candidates formed an essential part of the administrations' identity and formal presentation, in line with institutionalized expectations that bureaucracies act "without regard for the person" as Weber described it ideal-typically (Weber 2005, p. 186). My respondents emphasized recurrently the principle of equal treatment, some even cited the paragraph in the German constitution stating this for the civil service ("Article 33.2"). The head of the vocational training unit in administration A underlined for instance: "We don't differentiate. It doesn't matter for us whether a Turk, an Arab or someone with a Finnish background or a German is sitting in front of us. It is a question of the performance and if you confirm the performance here [in the interview situation] you will get an offer" (Interview A3.1, \$94).

However, the observed interview situations signal that categorical distinctions and stereotypes nevertheless mattered, yet with more ambivalent effects on the inclusion of candidates of immigrant origin. This became particularly visible in the exchange among officers after each interview. They discussed whether a candidate would fit into the team, commented on the personality (e.g. "open character", "fits into the administration", "typical dropout") and shared past experiences with similar "types", which helped to reduce uncertainty about a candidate's suitability. The officers negotiated expectations on future staff members which were not covered by the criteria on their standardized sheets but mattered for the decision-making. As this officer explained: "Afterwards in the decision-making process, i.e. when I have six applicants on paper and two or three of them are not entirely clear [...], this admittedly subjective impression can of course make the difference" (Interview A3.2, \$35). While such 'subjective impressions' provided scope for stereotypes that helped reduce uncertainty, it was difficult to observe to what extent they also drew on ethnic stereotypes. Stereotypes often work unconsciously, and the officers could hardly openly share them given that they had to demonstrate compliance with the principle of equal treatment to secure legitimacy.

Still, some observations show how categorical distinctions informed the evaluation of skills and suitability - here in a way that was beneficial for the selection of candidates of immigrant origin. Several trainees of immigrant origin said that they had been complimented in the job interviews for their good German skills. This was also the case in one of the interviews I observed in administration A. The candidate had migrated from Turkey to Germany only some years earlier. The head of the vocational training unit praised him for his good German and emphasized his "impressive communication skills" in the discussion among the participating officers (observation protocol A1, \$33). The officer explained to me that they often had applicants with Turkish background who would then "speak typically Turkish-German" - alluding to the slang of young people in immigrant neighbourhoods -, emphasizing that this was not the case with him (observation protocol A1, \$33). On their evaluation sheets, the officers marked good scores for the criterion "verbal skills". This positive assessment was also based on categorical distinctions and stereotypes insofar as it was precisely the candidate's individual 
difference from the expected deficits of the category he was associated with, that was perceived as an indicator of his suitability. Such ascriptions appeared as an easily available scheme that helped reduce uncertainty in the evaluation.

In administration B, categorical distinctions mattered in form of the category 'migration background' that was used for some time as an informal criterion in the candidate selection. As described above, respective candidates were placed on higher positions in the ranking in response to a target for the share of trainees with a migration background in the district's 'intercultural opening' policy that had been tightly controlled by the former district's mayor. This points again to the impact of organisational programmes and personnel on recruitment-related decisions. The use of the "migration background' can be described with Luhmann's concept of "useful illegality" (Luhmann 1964, p. 304). Deviating from the formal criteria was 'useful' for the officers because it allowed responding to conflicting organisational requirements and institutionalized expectations: demonstrating compliance with the political objective in the short term and in an efficient way without having to change the established formal procedures; and considering applicants with a migration background while formally presenting 'difference-blind' recruitment.

These examples illustrate how recruitment officers may informally draw on categorical distinctions in decisions over candidates, also in the organisational context of public administrations that are characterized by standardized procedures and by a formal self-description emphasizing the meritocratic, 'difference-blind' selection. This responds to different organisational needs: to reduce uncertainty concerning a candidate's suitability and to secure legitimacy by demonstrating compliance with institutionalized expectations on administrative recruitment while limiting the effort invested. For candidates of immigrant origin, this may not only lead to discrimination but also have beneficial effects, especially in an institutional context in which their recruitment is promoted.

\section{Conclusion}

This article investigated how public administrations shape the access of individuals of immigrant origin to their workforce, aiming to shed light on the role of organisations for the professional trajectories of immigrants and their children. The comparative analysis of recruitment practices in local administrations in the German state of Berlin showed three decisive elements of decision-making affecting the inclusion of individuals of immigrant origin. These are, first, decisions regarding advertisement strategies. Active advertisement may lower barriers stemming from lacking networks to people working in public administration; refraining from it contributes to perpetuate these barriers. Second, decisions regarding formal selection criteria matter. Administrations may "institutionally discriminate" (Feagin 1977; Gomolla and Radtke 2009) against immigrant descendants by drawing on school performance assessments and thus reproducing disadvantages produced or reinforced in the education system - or they may choose criteria independent from school assessments. Third, decisions over individual candidates affect the access to jobs if they informally draw on categorical distinctions and stereotypes. The analysis illustrated that this can have ambivalent effects. While candidates of immigrant or ethnic minority background risk discrimination, their background can also be positively evaluated if individual performance contrasts with 
negative stereotypes, or if a 'migration background' becomes politically valued in the context of policies aiming at increasing workforce diversity.

In pointing to the importance of decisions regarding advertisement and formal selection criteria, the findings contribute to the literature on organisational discrimination by drawing attention to mechanisms that have been less researched. Especially in the case of public administrations, advertisement strategies and formal criteria seem to play a key role for the access to employment. Public administrations often have highly formalized and standardized procedures and are particularly expected to conform to legal norms of equal treatment. Respecting formal procedures is an essential part of their self-description presented to the environment. The informal mechanisms that are often documented in the literature as affecting the access of individuals of immigrant or ethnic minority background to jobs - network-based hiring and decisions based on categorical distinctions and stereotypes - may still matter but the scope is much smaller, and they risk endangering an administration's legitimacy.

Further, drawing on approaches from organisational sociology (Luhmann 2000; March and Simon 1993; Meyer and Rowan 1977), the article elucidates organisational rationalities shaping recruitment-related decision-making. Decisions appear to be primarily informed by pragmatic considerations regarding the need and the effort required to change established routines; the principle of equal opportunities was secondary. This corresponds to findings from studies on workplace accommodation of (religious) diversity that demonstrate the importance of instrumental over moral-universal argumentations (Adam and Rea 2018). Different requirements on organisational practice interplayed in the recruitment-related decisions: to reduce uncertainty about the suitability of candidates and the effectiveness of procedures, and to demonstrate compliance with institutionalized expectations on recruitment practices - including political objectives to increase workforce diversity -, while at the same time respecting internal efficiency needs. The analysis further shows how negative stereotypes about potential staff members of immigrant origin, e.g. as lacking qualification and suitability, matter to balance out these partly contradictory requirements. Such stereotypes may, on the one hand, support certain practices by reducing uncertainty regarding appropriate strategies, criteria and the suitability of candidates. On the other hand, they may be used a posteriori to justify and legitimize decisions, established routines and resulting inequalities. While it has been often documented that employers draw on categorical distinctions and stereotypes in the evaluation of individual candidates, the analysis points to their broader significance across decision-making moments in the recruitment process. Organisations (re-)produce ethnic stereotypes with their decision-making because they serve practical purposes.

Moreover, the cross-case comparison illustrates that recruitment practices are also shaped by the organisational contexts, indicating structural elements that contribute to organisational differences in 'inclusiveness' or 'exclusiveness'. With the systems theory approach (Luhmann 2000), we can identify specifically the role of formal programmes in place (or not) regarding 'intercultural opening' and future-oriented recruitment and of the interest and support by the personnel in the relevant decision-making positions, primarily the mayor. In showing the importance of internal structures, the findings resonate previous research on organisational diversity policies that emphasizes the positive effects of structures establishing responsibility for workforce diversity in an 
organisation (Kalev et al. 2006). In addition, the findings contribute to the literature in pointing to the importance of individual agency within an organisation, notably of the actors in leadership positions, and in showing that not only diversity policies matter but also more general structural support for changing established routines.

The research results also have implications for policy and practice. They suggest that increasing the share of staff members of immigrant origin in public administration requires particularly appropriate advertisement strategies and a critical revision of formal procedures regarding indirect discriminatory effects. Further, to change established recruitment practices, the officers in charge need leadership support in form of futureoriented HR strategies and the provision of sufficient resources.

Certainly, the focus on organisational decision-making can only shed light on some of the factors influencing inclusion in employment. Organisational factors interplay with institutional and individual factors, which could only be touched upon in this article. They include rules, policies and discourses concerning e.g. the civil service and migration-induced diversity, which differ between countries and cities, and they include the resources and agency of immigrants and their children. Further comparative research is thus needed on both organisational characteristics and on their interplay with institutional contexts and individuals' resources and agency. Focusing on the crucial role of organisations advances our understanding of the factors shaping the labour market inclusion of immigrants and their children.

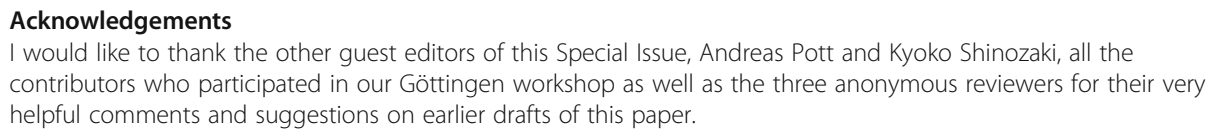

\section{Declaration}

Competing interests

Not applicable.

Received: 12 May 2020 Accepted: 25 February 2021

Published online: 24 June 2021

\section{References}

Abgeordnetenhaus von Berlin. (2010). Gesetz zur Regelung von Partizipation und Integration in Berlin. Berlin: Abgeordnetenhaus von Berlin.

Acker, J. (2006). Inequality regimes: Gender, class, and race in organizations. Gender \& Society, 20(4), 441-464.

Adam, I., \& Rea, A. (2018). The three "i"s of workplace accommodation of Muslim religious practices: Instrumental, internal, and informal. Ethnic and Racial Studies, 41(15), 2711-2730. 
Becker, B., \& Reimer, D. (Eds.) (2010). Vom Kindergarten bis zur Hochschule: Die Generierung von ethnischen und sozialen Disparitäten in der Bildungsbiographie. Wiesbaden: VS Verlag.

Bommes, M. (1996). Ausbildung in Großbetrieben: Einige Gründe, warum ausländische Jugendliche weniger Berücksichtigung finden. In R. Kersten, D. Kiesel, \& S. Sargut (Eds.), Ausbilden statt Ausgrenzen. Jugendliche ausländischer Herkunft in Schule, Ausbildung und Beruf (pp. 31-44). Frankfurt am Main: Haag + Herchen.

BQN Berlin (2014). Entwicklung des Anteils neuer Auszubildender mit Migrationshintergrund im Öffentlichen Dienst Berlins 20062013. Berlin: BQN.

Crul, M., Schneider, J., \& Lelie, F. (Eds.) (2012). The European second generation compared. Does the integration context matter? Amsterdam: Amsterdam Univ. Press.

Der Beauftragte des Senats von Berlin für Integration und Migration (2005). Vielfalt fördern - Zusammenhalt stärken. Das Integrationskonzept für Berlin. Berlin: Der Beauftragte des Senats für Integration und Migration.

Diehl, C., Hunkler, C., \& Kristen, C. (Eds.) (2016). Ethnische Ungleichheiten im Bildungsverlauf: Mechanismen, Befunde, Debatten. Wiesbaden: Springer VS

Dobbin, F., Schrage, D., \& Kalev, A. (2015). Rage against the Iron cage: The varied effects of bureaucratic personnel reforms on diversity. American Sociological Review, 80(5), 1014-1044.

Dobusch, L. (2017). Diversity discourses and the articulation of discrimination: The case of public organisations. Journal of Ethnic and Migration Studies, 43(10), 1644-1661.

Ette, A., Stedtfeld, S., Sulak, H., \& Brückner, G. (2016). Erhebung des Anteils von Beschäftigten mit Migrationshintergrund in der Bundesverwaltung: Ergebnisbericht im Auftrag des Ressortarbeitskreises der Bundesregierung. Wiesbaden: Bundesinstitut für Bevölkerungsforschung.

Feagin, J. R. (1977). Indirect institutionalized discrimination: A typological and policy analysis. American Politics Quarterly, 5(2), $177-200$.

George, A. L., \& Bennett, A. (2005). Case studies and theory development in the social sciences. Cambridge, Mass: The MIT Press.

Gomolla, M., \& Radtke, F.-O. (2009). Institutionelle Diskriminierung: Die Herstellung ethnischer Differenz in der Schule (3rd ed.). Wiesbaden: VS Verlag.

Groeneveld, S., \& Verbeek, S. (2012). Diversity policies in public and private sector organizations: An empirical comparison of incidence and effectiveness. Review of Public Personnel Administration, 32(4), 353-381.

Hadjar, A., \& Scharf, J. (2019). The value of education among immigrants and non-immigrants and how this translates into educational aspirations: A comparison of four European countries. Journal of Ethnic and Migration Studies, 45(5), $711-734$.

Heath, A. F., \& Cheung, S. Y. (Eds.) (2007). Unequal chances: Ethnic minorities in Western labour markets. Oxford: Oxford Univ. Press.

Imdorf, C. (2008). Migrantenjugendliche in der betrieblichen Ausbildungsplatzvergabe: Auch ein Problem für Kommunen. In M. Bommes, \& M. Krüger-Potratz (Eds.), Migrationsreport 2008: Fakten—Analysen—Perspektiven (pp. 113-158). Frankfurt am Main: Campus.

Jenkins, R. (1986). Racism and recruitment: Managers, organisations and equal opportunity in the labour market. Cambridge: Cambridge Univ. Press.

Kalev, A., Dobbin, F., \& Kelly, E. (2006). Best practices or best guesses? Assessing the efficacy of corporate affirmative action and diversity policies. American Sociological Review, 71(4), 589-617.

Kasinitz, P., \& Rosenberg, J. (1996). Missing the connection: Social isolation and employment on the Brooklyn waterfront. Social Problems, 43(2), 180-196.

Keskiner, E., \& Crul, M. (2017). How to reach the top? Fields, forms of capital, and strategies in accessing leadership positions in France among descendants of migrants from Turkey. Ethnic and Racial Studies, 40(2), 283-300.

Kirschenman, J., \& Neckerman, K. M. (1991). "We'd Love to Hire Them, But...": The Meaning of Race to Employers. In C. Jencks, \& P. E. Peterson (Eds.), The Urban Underclass (pp. 203-232). Washington D.C: Brookings Institution Press.

Kogan, I. (2007). Working through barriers: Host country institutions and immigrant labour market performance in Europe. Dordrecht: Springer.

Konyali, A. (2017). International opportunities on the way up: Alternative career paths of descendants of migrants from Turkey in the field of professional business services. Ethnic and Racial Studies, 40(2), 264-282.

Kühl, S. (2013). Organizations: A systems approach. Farnham, Surrey: Gower.

Lang, C. (2017). Von 'typischen' und 'untypischen' Einwanderungsbezirken: Migrationsbedingte Vielfalt und die 'Interkulturelle Öffnung' städtischer Verwaltungen. In M. Barbehön, \& S. Münch (Eds.), Variationen des Städtischen—Variationen lokaler Politik (pp. 351-373). Wiesbaden: Springer VS.

Lang, C. (2019). Die Produktion von Diversität in städtischen Verwaltungen. Wandel und Beharrung von Organisationen in der Migrationsgesellschaft. Wiesbaden: Springer.

Lang, C. (2020). Workforce diversity policies in practice: Drivers and barriers in local administrations. Ethnic and Racial Studies, 43(11), 1961-1980.

Lang, C., Pott, A., \& Schneider, J. (2018). Erfolg nicht vorgesehen: Sozialer Aufstieg in der Einwanderungsgesellschaft - und was ihn so schwer macht (2nd updated ed). Münster: Waxmann.

Luhmann, N. (1964). Funktionen und Folgen formaler Organisation. Berlin: Duncker \& Humblot.

Luhmann, N. (2000). Organisation und Entscheidung. Opladen: Westdt. Verl.

March, J. G. (1990). Decisions and organizations (Repr). Cambridge, Mass: Blackwell.

March, J. G., \& Simon, H. A. (1993). Organizations (2nd ed). Cambridge, Mass: Blackwell.

Marsden, P. V., \& Gorman, E. H. (2001). Social networks, job changes, and recruitment. In I. Berg, \& A. L. Kalleberg (Eds.), Sourcebook of labor markets: Evolving structures and processes (pp. 467-502). Boston: Springer.

Meyer, J. W., \& Rowan, B. (1977). Institutionalized organizations: Formal structure as myth and ceremony. American Journal of Sociology, 83(2), 340-363.

Meziani-Remichi, Y., \& Maussen, M. (2017). Recruitment in public administrations: Diversity policies and selection practices in a French city. Journal of Ethnic and Migration Studies, 43(10), 1679-1695.

Midtbøen, A. H. (2014). Discrimination of the second generation: Evidence from a field experiment in Norway. Journal of International Migration and Integration, 17(1), 253-272. 
Midtbøen, A. H. (2015). The context of employment discrimination: Interpreting the findings of a field experiment. The British Journal of Sociology, 66(1), 193-214.

Moss, P., \& Tilly, C. (2001). Stories employers tell: Race, skill, and hiring in America. New York: Russell Sage Foundation.

Nohl, A.-M., Schittenhelm, K., Schmidtke, O., \& Weiss, A. (2014). Work in transition: Cultural capital and highly skilled migrants' passages into the labour market. Toronto: University of Toronto Press.

OECD (2018). Settling in 2018: Indicators of immigrant integration. Paris: OECD Publishing.

Pager, D., \& Karafin, D. (2009). Bayesian bigot? Statistical discrimination, stereotypes, and employer decision making. The ANNA LS of the American Academy of Political and Social Science, 621(1), 70-93.

Phelps, E. S. (1972). The statistical theory of racism and sexism. The American Economic Review, 62(4), 659-661.

Pichler, F. (2011). Success on European labor markets: A cross-national comparison of attainment between immigrant and majority populations. International Migration Review, 45(4), 938-978.

Rivera, L. A. (2012). Diversity within reach: Recruitment versus hiring in elite firms. The Annals of the American Academy of Political and Social Science, 639(1), 71-90.

Salikutluk, Z. (2016). Why do immigrant students aim high? Explaining the aspiration-achievement paradox of immigrants in Germany. European Sociological Review, 32(5), 581-592.

Scherr, A., Janz, C., \& Müller, S. (2015). Diskriminierung in der beruflichen Bildung: Wie migrantische Jugendliche bei der Lehrstellenvergabe benachteiligt werden. Wiesbaden: Springer VS.

Scott, W. R. (2008). Institutions and organizations: Ideas and interests (3rd ed.). Los Angeles, Calif: [u.a.]: Sage.

Stainback, K., Tomaskovic-Devey, D., \& Skaggs, S. (2010). Organizational approaches to inequality: Inertia, relative power, and environments. Annual Review of Sociology, 36(1), 225-247.

Statistisches Bundesamt (2014). Bevölkerung und Erwerbstätigkeit. Bevölkerung mit Migrationshintergrund - Ergebnisse des Mikrozensus 2013. Wiesbaden: Statistisches Bundesamt.

Statistisches Bundesamt (2018). Bevölkerung und Erwerbstätigkeit: Bevölkerung mit Migrationshintergrund-Ergebnisse des Mikrozensus 2017. Wiesbaden: Statistisches Bundesamt.

Strauss, A., \& Corbin, J. (1990). Basics of qualitative research: Grounded theory procedures and techniques. Newbury Park: SAGE.

van Tubergen, F., Maas, I., \& Flap, H. (2004). The economic incorporation of immigrants in 18 Western societies: Origin, destination, and community effects. American Sociological Review, 69(5), 704-727.

Waldinger, R., \& Lichter, M. I. (2003). How the other half works: Immigration and the social Organization of Labor. Berkeley: University of California Press.

Weber, M. (2005). Wirtschaft und Gesellschaft - Die Wirtschaft und die gesellschaftlichen Ordnungen und Mächte. Nachlaß. Teilband 4. (E. Hanke \& T. Kroll, Eds.). Tübingen: Mohr.

Windolf, P. (1986). Recruitment, selection, and internal labour markets in Britain and Germany. Organization Studies, 7(3), 235254.

Zanoni, P., \& Janssens, M. (2015). The power of diversity discourses at work: On the interlocking nature of diversities and occupations. Organization Studies, 36(11), 1463-1483.

Zschirnt, E., \& Ruedin, D. (2016). Ethnic discrimination in hiring decisions: A meta-analysis of correspondence tests 1990-2015. Journal of Ethnic and Migration Studies, 42(7), 1115-1134.

\section{Publisher's Note}

Springer Nature remains neutral with regard to jurisdictional claims in published maps and institutional affiliations.

\section{Submit your manuscript to a SpringerOpen ${ }^{\circ}$ journal and benefit from:}

- Convenient online submission

- Rigorous peer review

- Open access: articles freely available online

- High visibility within the field

- Retaining the copyright to your article

Submit your next manuscript at $\boldsymbol{\nabla}$ springeropen.com 